\title{
Field performance of maize (Zea mays L.) cultivars under drought stress
}

\author{
Kazem GHASSEMI-GOLEZANI ${ }^{1}$, Shabnam HEYDARI $^{1}$, Bahareh DALIL ${ }^{2}$
}

Received September 09, 2016; accepted December 31, 2017.

Delo je prispelo 09. septembra 2016, sprejeto 31. decembra 2017.

\begin{abstract}
This research was carried out in 2014 at the Research Farm of the University of Tabriz, Iran. The experiment was arranged as split plot on the basis of randomized complete block with three replicates to assess the effects of four irrigation intervals (irrigations after 60, 80, 100 and $120 \mathrm{~mm}$ evaporation) on physiological and agronomical traits of three cultivars of maize (Zea mays L.; 'SC704', 'NS640', 'DC303': late, mid and early maturing, respectively). Irrigation intervals and maize cultivars were assigned to the main and sub-plots, respectively. Leaf temperature of all maize cultivars significantly increased, but chlorophyll content index, maximum efficiency of photosystem II, number of grains per plant, 1000 grain mass, plant biomass, grain yield and harvest index significantly decreased with increasing irrigation intervals. Late maturing cultivar ('SC704') was superior in all studied traits, followed by mid ('NS640') and early ('DC303') maturing cultivars. It was concluded that water limitation can potentially reduce performance of maize cultivars in the field, but the extent of this reduction depends on genotype and severity of stress.
\end{abstract}

Key words: chlorophyll content; leaf temperature; maize; photosystem II; drought stress

\section{IZVLEČEK}

\section{USPEVANJE SORT KORUZE (Zea mays L.) V RAZMERAH SUŠNEGA STRESA}

Raziskava je bila opravljena v sezoni 2014 na Research Farm of the University of Tabriz, Iran. Poskus je bil zasnovan kot poskus $\mathrm{z}$ deljenkami na osnovi popolnega naključnega bločnega poskusa $\mathrm{s}$ tremi ponovitvami za ovrednotenje učinkov štirih načinov namakanja (namakanje po 60, 80, 100 in $120 \mathrm{~mm}$ evaporacije) na osnovi fizioloških in agronomskih lastnosti treh sort koruze (Zea mays L.; 'SC704', 'NS640', 'DC303': zgodnje, srednje in pozno dozorevajoča sorta). Načini namakanja so bili vrednoteni na glavnih ploskvah, sorte koruze na podploskvah. Temperatura lista je pri vseh sortah značilno naraščala $\mathrm{z}$ večanjem intervala namakanja, lastnosti kot so indeks vsebnosti klorofila, maksimalna učinkovitost fotosistema II, število zrn na rastlino, masa 1000 zrn, biomasa rastlin, pridelek zrnja in žetveni indeks pa so se z večanjem intervala namakanja značilno zmanjšale. Pozno dozorevajoča sorta ('SC704') je bila v vseh preučevanih lastnostih najboljša, sledili sta ji srednje ('NS640') in zgodaj ('DC303') dozorevajoči sorti. Ugotovljeno je bilo, da pomanjkanje vode lahko potencialno zmanjša uspevanje koruze, a je obseg zmanjšanja odvisen od genotipa in jakosti stresa.

Ključne besede: vsebnost klorofila; temperature lista; koruza; fotosistem II, sušni stres

\section{INTRODUCTION}

Maize (Zea mays L.), also known as corn, is an important crop worldwide, not only because it is the third cereal after wheat and rice, but also because of its various uses and increasing demand (Huang et al., 2006). Maize had its origin in a semi-arid area, but it is not a reliable crop for growing under dry-land conditions, with limited or erratic rainfall (Campos et al., 2004). Monneveux et al. (2006) reported that seasonal drought was the most important limiting factor for producing maize in the world.

Iran is placed in arid and semi-arid region and water shortage is one of the basic problems of agriculture in that area. The crop experiences drought stress from late vegetative stages until maturity (Soltani et al., 2001). When full crop requirements are not met, water deficit

1 Department of Plant Eco-physiology, Faculty of Agriculture, University of Tabriz, Tabriz, Iran; *corresponding author: golezani@gmail.com

2 Department of Agriculture, Payame Noor Universtiy, Tehran, Iran 
in the plant can develop to a point, where physiological activities, crop growth and yield are affected. The manner in which water deficit affects crop growth and yield varies with crop species and growth period (Badoni et al., 2009). It has been shown that growth of maize is sensitive to water limitation (Aslam et al., 2013) and water deficit can limit the performance of this crop in the field (Ghassemi-Golezani et al., 2011).

Drought stress can reduce the photosynthetic rate indirectly by closure of the stomata or directly by a reduction of the photosynthetic capacity of the leaves (Sabir et al., 2009). Closure of stomata results in higher leaf temperature due to the loss of the ability for transpiration cooling under water limitation ( $\mathrm{Lu}$ et al., 1997). Increasing leaf temperature could lead to the combination of drought and heat stresses, leading to leaf scorch (Mohammadian et al., 2005). Dalil and Ghassemi-Golezani (2012) reported that leaf temperature and differences in leaf and air temperatures increase with increasing irrigation intervals in Ksc301 cultivar of maize.

Chlorophyll fluorescence is directly related to plant photosynthesis and the physiological state of vegetation. Therefore, chlorophyll fluorescence measurements have become a widely used method to study the functioning of the photosynthetic apparatus and are a powerful, nondestructive and reliable tool in plant physiology for study the effects of stress on PSII photochemistry (Brestic \& Zivcak, 2013). Many studies have shown that photochemical efficiency of photosystem II ( Fv / Fm) in plants decreases due to deactivation of antennae to prevent damage by harmful radicals that are formed under different stress conditions (Ghassemi-Golezani et al., 2008; Zarco-Tejada et al., 2009). Nevertheless, little information is available on the effect of drought stress on $\mathrm{Fv} / \mathrm{Fm}$ in maize cultivars.
Studies showed that the ratio of variable/maximum fluorescence $(\mathrm{Fv} / \mathrm{Fm})$ is a quantitative measure for the photochemical efficiency of photosystem II (maximum quantum yield of PSII). The accumulation of excessive excitation energy can cause photo-inhibition or photooxidation in the photosynthetic apparatus and the reduced values of $\mathrm{Fv} / \mathrm{Fm}$ indicate that a proportion of PSII reaction centers were damaged (GhassemiGolezani and Lotfi, 2015). Fv/Fm is the most common parameter which responds to drought stress (Gregoriou et al., 2007) and can be used as a physiological index for selecting osmotic stress tolerant cultivars (Paul Parkhill et al. 2001). According to Roohi et al. (2013) reduction in $\mathrm{Fv} / \mathrm{Fm}$ by drought stress was different. It has been reported that most of this variation was due to differences among crop species. Similar results revealed that the components of the photosynthetic apparatus could be damaged significantly in drought sensitive barley genotypes, while drought tolerant genotypes were relatively less affected. On the other hand, the value of $\mathrm{Fv} / \mathrm{Fm}$ in drought tolerant genotypes was significantly higher than that in drought sensitive genotypes under drought stress (Rong-Hua et al., 2006).

A better understanding of the physiological and agronomical traits of maize under drought stress would help in selecting the promising maize cultivars for drought resistance. We hypothesized that there were differences in physiological and yield responses among maize cultivars under drought stress. Therefore, the comparative study presented here was carried out under different irrigation intervals in order to (i) compare changes in leaf temperature, chlorophyll content and fluorescence, as parameters influencing photosynthesis in maize cultivars and (ii) determine the consequences for yield and yield component of cultivars.

\section{MATERIALS AND METHODS}

This research was carried out at the Research Farm of the University of Tabriz, Iran (latitude $38.050 \mathrm{~N}$, longitude $46.170 \mathrm{E}$, Altitude $1360 \mathrm{~m}$ above sea level) in 2014. The climate is characterized by mean annual precipitation of $245.75 \mathrm{~mm}$, mean annual temperature of $10{ }^{\circ} \mathrm{C}$, mean annual maximum temperature of $16.6{ }^{\circ} \mathrm{C}$ and mean annual minimum temperature of $4.2^{\circ} \mathrm{C}$.

The experimental design was split plot on the bases of randomized complete block in three replicates. Irrigation treatments $\left(I_{1}, I_{2}, I_{3}, I_{4}\right.$ : irrigation after 60,80 , 100 and $120 \mathrm{~mm}$ evaporation from class A pan, respectively) were located in main plots and cultivars ('SC704', 'NS640' and 'DC303': late, mid and early maturing, respectively) were assigned to sub plots. Seeds were first treated with $2 \mathrm{~g} \mathrm{~kg}^{-1}$ Mancozeb fungicide and then were hand sown in $5 \mathrm{~cm}$ depth of a sandy-loam soil with a density of 10 seeds per $\mathrm{m}^{2}$. At the same time, plots were fertilized with urea $(46 \% \mathrm{~N})$ at a rate of $200 \mathrm{~kg} \mathrm{ha}^{-1}$. Each plot consisted of nine rows of $2.5 \mathrm{~m}$ length, spaced $50 \mathrm{~cm}$ apart. All plots were irrigated immediately after sowing. Irrigation treatments were applied after seedling establishment. Hand weeding of the experimental area was carried out as required.

All of the physiological measurements were carried out just before irrigation at silking stage (R1). A plant from 
each plot was marked and temperature of leaves (top, middle and bottom leaves) was measured using an infrared thermometer (TES 1327, Taiwan). Chlorophyll content index (CCI) was measured by a portable chlorophyll-meter (CCM-200, Opti-Sciences, USA).

Fluorescence emission was monitored from the upper surface of the leaves. Dark-adapted leaves $(30 \mathrm{~min})$ were initially exposed to the weak modulate measuring beam, followed by exposure to saturated white light to estimate the initial $\left(\mathrm{F}_{0}\right)$ and maximum $(\mathrm{Fm})$ fluorescence values, respectively (Krause \& Weis, 1991). Variable fluorescence (Fv) was calculated by subtracting $\mathrm{F}_{0}$ from $\mathrm{Fm}$. The $\mathrm{Fv} / \mathrm{Fm}$ ratio measures the efficiency of excitation energy capture by open PSII reaction centers, representing the maximum capacity of light-dependent charge separation in PSII (Rizza et al., 2001).

At maturity, plants in $1 \mathrm{~m}^{2}$ of each plot were harvested and above ground biomass (plant biomass), number of grains per plant, 1000 grain mass, grain yield per unit area and harvest index. Analysis of variance appropriate to the experimental design was conducted, using MSTATC and SPSS. Means of each trait were compared according to Duncan multiple range test at $P \leq 0.05$. Excel software was used to draw figures.

\section{RESULTS}

Analysis of variance showed significant effects of irrigation and cultivar on leaf temperature, maximum efficiency of photosystem II (Fv/Fm), grains per plant, plant biomass, grain yield and harvest index $(P \leq 0.01)$. The interaction of these factors were also significant for grains per plant, plant biomass, grain yield and harvest index $(P \leq 0.01)$, but not for leaf temperature and $\mathrm{Fv} / \mathrm{Fm}$ $(P>0.05)$. Mean 1000 grain mass was significantly affected by cultivar $(P \leq 0.01)$ and interaction of irrigation $\times$ cultivar $(P>0.05)$.

Leaf temperature of plants significantly increased under $I_{3}$ and $I_{4}$ (Fig. 1A), but there was no significant difference between $\mathrm{I}_{1}$ and $\mathrm{I}_{2}$ and also between $\mathrm{I}_{3}$ and $\mathrm{I}_{4}$ (Fig. 1A). Early maturing cultivar ('DC303') had the highest leaf temperature, which was significantly reduced in mid ('NS640') and late ('SC704') maturing cultivars (Fig. 1B).
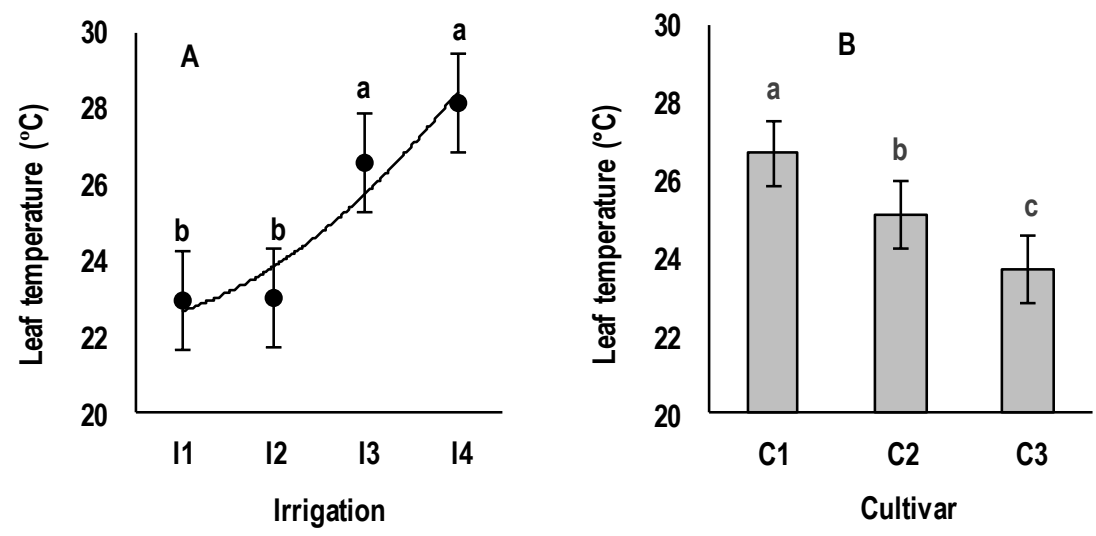

Figure 1: Mean leaf temperature of maize for irrigation treatments (A) and cultivars (B)

I1, I2, I3, I4: Irrigation after 60, 80, 100 and $120 \mathrm{~mm}$ evaporation, respectively

C1, C2, C3: 'DC303', 'NS640' and 'SC704' cultivars, respectively

Although, chlorophyll content index (CCI) of maize plants was not significantly affected by irrigation treatments and cultivars, the highest and the lowest CCI were obtained under $I_{1}$ and $I_{4}$, respectively (Fig. 2A).
Chlorophyll content index of late ('SC704') and mid ('NS640') maturing cultivars was greater than that of early maturing cultivar ('DC303') (Fig. 2B). 

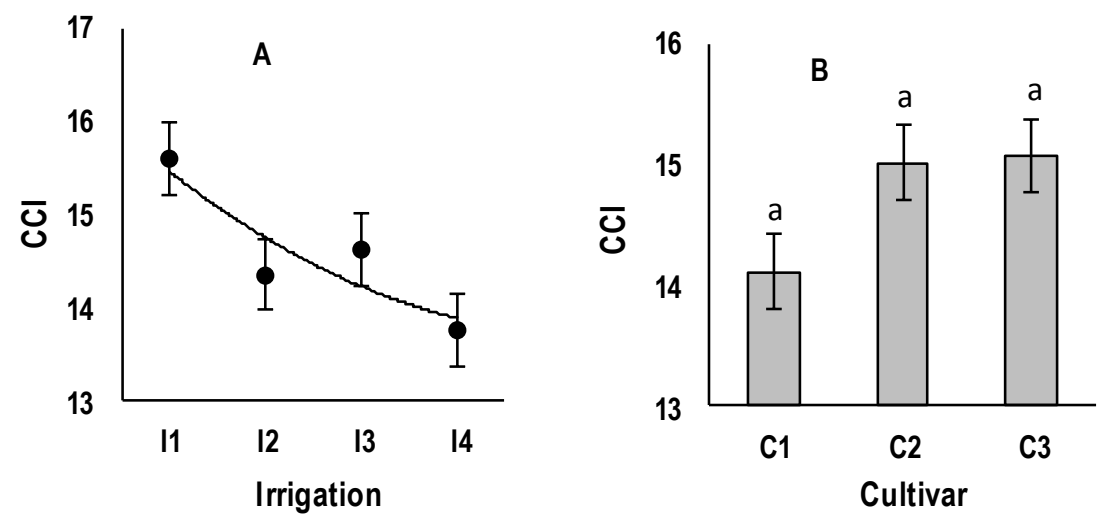

Figure 2: Chlorophyll content index of maize for irrigation treatments (A) and cultivars (B) I1, I2, I3, I4: irrigation after 60, 80, 100 and $120 \mathrm{~mm}$ evaporation, respectively C1, C2, C3: 'DC303', 'NS640' and 'SC704' cultivars, respectively

Maximum efficiency of PSII $(F \mathrm{v} / F \mathrm{~m})$ significantly declined under moderate $\left(I_{3}\right)$ and severe water deficit $\left(\mathrm{I}_{4}\right)$, compared with well-watering $\left(\mathrm{I}_{1}\right)$ (Fig. 3A). The lowest and the highest $F \mathrm{v} / F \mathrm{~m}$ were recorded for 'DC303' (early maturing cultivar) and 'SC704' (late maturing cultivar), respectively. However, differences in $F v / F m$ between 'SC704' and 'NS640' (mid maturing cultivar) and also between 'NS640' and 'DC303' were not statistically significant (Fig. 3B).
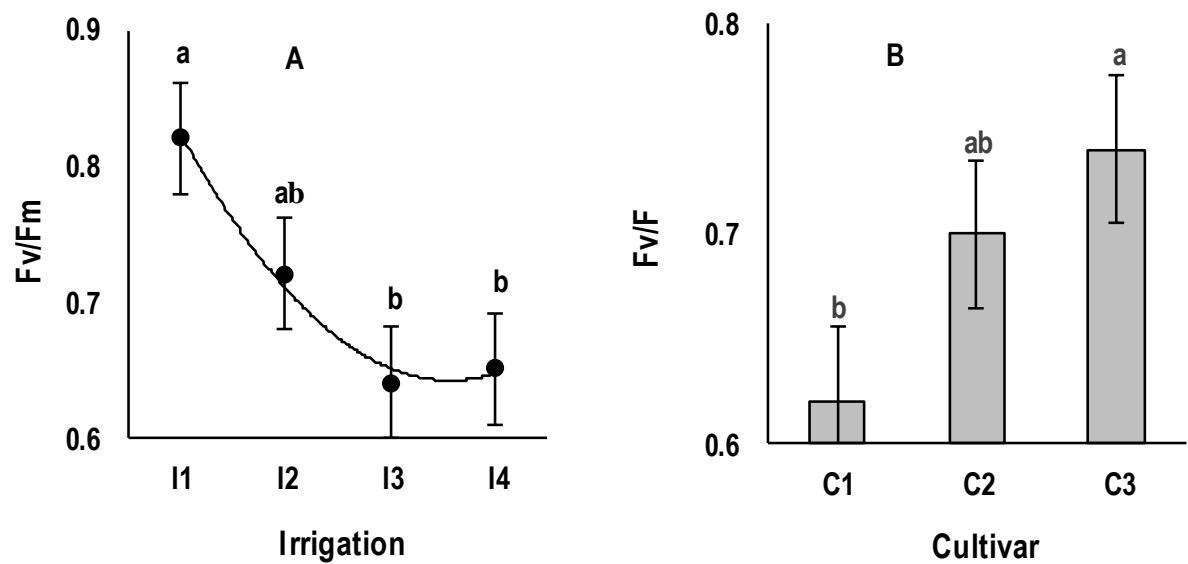

Figure 3: Maximum efficiency of photosystem II in dark- adapted leaves of maize for irrigation treatments (A) and cultivars (B)

I1, I2, I3, I4: irrigation after 60, 80, 100 and $120 \mathrm{~mm}$ evaporation, respectively

C1, C2, C3: 'DC303', 'NS640' and 'SC704' cultivars, respectively

Mean number of grains per plant, plant biomass and grain yield per unit area and harvest index of all cultivars decreased with decreasing water availability. The greatest reduction in these traits due to water deficit was observed in 'DC303' (early maturing cultivar), compared with other cultivars (Table 1). The highest grains per plant, 1000 grain mass, biological and grain yields per unit area and harvest index under different irrigation treatments were produced by 'SC704' (late maturing cultivar), followed by 'NS640' (mid maturing cultivar) (Table 1). 
Field performance of maize (Zea mays L.) cultivars under drought stress

Table 1: Means of yield components and grain yield of maize for interaction of irrigation intervals $\times$ cultivars

\begin{tabular}{|c|c|c|c|c|c|c|}
\hline $\begin{array}{l}\text { Irrigation } \\
\text { treatments }\end{array}$ & Cultivar & $\begin{array}{c}\text { Grains } \\
\text { per } \\
\text { plant } \\
\end{array}$ & $\begin{array}{c}1000 \text { grain } \\
\text { mass } \\
(\mathrm{g})\end{array}$ & $\begin{array}{l}\text { Plant biomass } \\
\qquad\left(\mathrm{g} / \mathrm{m}^{2}\right)\end{array}$ & $\begin{array}{r}\text { Grain } \\
\text { yield } \\
\left(\mathrm{g} / \mathrm{m}^{2}\right) \\
\end{array}$ & $\begin{array}{c}\text { Harvest } \\
\text { index } \\
(\%) \\
\end{array}$ \\
\hline \multirow{3}{*}{$\mathrm{I}_{1}$} & $\mathrm{C}_{1}$ & $351 \mathrm{c}$ & $132.45 \mathrm{e}$ & $1770.1 \mathrm{c}$ & $445.77 \mathrm{f}$ & $25.18 \mathrm{e}$ \\
\hline & $\mathrm{C}_{2}$ & $386 b$ & $145.52 \mathrm{c}$ & $1856.47 \mathrm{~b}$ & $533.98 \mathrm{c}$ & $29.18 \mathrm{c}$ \\
\hline & $\mathrm{C}_{3}$ & $401 \mathrm{a}$ & $169.45 a$ & 1951.1a & $628.23 \mathrm{a}$ & $36.77 \mathrm{a}$ \\
\hline \multirow{5}{*}{$\mathrm{I}_{2}$} & Mean & 379.33 & 149.14 & 1859.22 & 535.99 & 30.38 \\
\hline & $\mathrm{C}_{1}$ & $305 f$ & $134.82 \mathrm{e}$ & $1532.07 \mathrm{e}$ & $382.09 \mathrm{~h}$ & $24.93 \mathrm{e}$ \\
\hline & $\mathrm{C}_{2}$ & $343.67 d$ & $143.52 \mathrm{~cd}$ & $1624.4 d$ & $474.11 \mathrm{e}$ & $28.75 \mathrm{c}$ \\
\hline & $\mathrm{C}_{3}$ & $389.67 b$ & 166.2ab & $1762.73 \mathrm{c}$ & $613.05 b$ & $36.1 \mathrm{a}$ \\
\hline & Mean & 346.11 & 148.18 & 1639.73 & 489.75 & 29.93 \\
\hline \multirow{3}{*}{$\mathrm{I}_{3}$} & $\mathrm{C}_{1}$ & $206 \mathrm{i}$ & $129.81 \mathrm{f}$ & $1228.9 \mathrm{j}$ & $258.07 \mathrm{j}$ & $20.99 f$ \\
\hline & $\mathrm{C}_{2}$ & $290 \mathrm{~g}$ & $138.72 d$ & $1374.1 \mathrm{~h}$ & $398.23 \mathrm{~g}$ & $28.97 \mathrm{c}$ \\
\hline & $\mathrm{C}_{3}$ & $344 d$ & $161.41 \mathrm{~b}$ & $1516.77 f$ & $541.21 \mathrm{c}$ & $34.77 \mathrm{~b}$ \\
\hline \multirow{5}{*}{$\mathrm{I}_{4}$} & Mean & 280 & 143.31 & 1373.26 & 399.17 & 28.24 \\
\hline & $\mathrm{C}_{1}$ & $111.33 \mathrm{j}$ & $128.81 \mathrm{f}$ & $1102.8 \mathrm{k}$ & $141.36 \mathrm{k}$ & $12.81 \mathrm{~g}$ \\
\hline & $\mathrm{C}_{2}$ & $262.67 \mathrm{~h}$ & $144.44 \mathrm{c}$ & $1320.9 \mathrm{i}$ & $360.69 \mathrm{i}$ & $27.29 \mathrm{~d}$ \\
\hline & $\mathrm{C}_{3}$ & $317.67 \mathrm{e}$ & $161.01 \mathrm{~b}$ & $1456.5 \mathrm{~g}$ & $495.51 d$ & $34.21 \mathrm{~b}$ \\
\hline & Mean & 230.57 & 144.75 & 1293.4 & 332.52 & 24.77 \\
\hline \multirow{3}{*}{$\begin{array}{l}\text { Means for } \\
\text { cultivars }\end{array}$} & $\mathrm{C}_{1}$ & 243.33 & 131.47 & 1408.47 & 306.82 & 20.98 \\
\hline & $\mathrm{C}_{2}$ & 320.58 & 143.05 & 1543.97 & 441.75 & 28.55 \\
\hline & $\mathrm{C}_{3}$ & 363.08 & 164.52 & 1671.78 & 569.5 & 35.46 \\
\hline
\end{tabular}

$\mathbf{I}_{1}, \mathbf{I}_{2}, \mathbf{I}_{3}, \mathbf{I}_{\mathbf{4}}$ : Irrigation after $60,80,100$ and $120 \mathrm{~mm}$ evaporation, respectively

$\mathrm{C}_{1}, \mathrm{C}_{2}, \mathrm{C}_{3}$ : Maize cultivars of 'DC303', 'NS640' and 'SC704', respectively

\section{DISCUSSION}

Increasing leaf temperature with decreasing water availability (Fig. 1A) was the result of stomata closure under drought stress. Under drought stress, rate of water uptake cannot match the transpiration rate and stomata close to maintain the plant water balance (Shahenshah $\&$ Isoda, 2010). As a result, leaf temperature rises and may even exceed air temperature (Larcher, 2000). The significant differences among genotypes for leaf temperature (Fig. 1B) indicate appreciable amount of variability among the genotypes. Increasing in leaf temperature due to water loss could reduce net photosynthesis which correlates with a decrease in the activation state of Rubisco in both $\mathrm{C}_{3}$ and $\mathrm{C}_{4}$ plants (Salvucci and Crafts-Brandner, 2004).
Decreasing chlorophyll content under drought stress (Fig. 2A) may be partly resulted from low nitrogen uptake (Rimski-Korsakov et al., 2009), oxidative damage of reactive oxygen species (Lotfi et al., 2015) and disorganization of thylakoid membranes (Ladjal et al., 2000). Decreased or unchanged chlorophyll levels during drought stress have been reported in many species, depending on the duration, severity of drought (Anjum et al., 2011) and sensitivity of cultivars (Valifard et al., 2012). The highest chlorophyll content index in late maturing cultivar ('SC704') (Fig. 2B), could be the result of lower leaf temperature in this cultivars (Fig. 1B).

The low $F \mathrm{v} / F \mathrm{~m}$ values in maize cultivars under drought stress (Fig. 3A) could have resulted from the inactivity 
of the reaction centers, which may favor greater energy dissipation in the form of heat and fluorescence, as deduced from the high $F \mathrm{v} / F \mathrm{~m}$ values (GhassemiGolezani and Lotfi, 2015). This may be associated with increased heat sinks (heat sink centers or silent centers), which may absorb light in a similar manner as that of active reaction centers, but are unable to store the excitation energy as redox energy and dissipate their total energy as heat (Hermans et al., 2003). The $F \mathrm{v} / F \mathrm{~m}$ ratio is frequently used as an indicator of the photoinhibitor or other injury caused to the PSII complexes (Rohacek, 2002). The higher $F \mathrm{v} / F \mathrm{~m}$ in late maturing cultivar ('SC704') (Fig. 3B) may be related with lower leaf temperature of this cultivar under different irrigation treatments, compared with other cultivars (Fig. 1B).

Increasing leaf temperature (Fig. 1A) and decreasing chlorophyll content (Fig. 2A) and Fv / Fm (Fig. 3A) are the possible reasons for reduction of biomass accumulation in maize plants under drought stress, which is strongly related with harvest index (Table 1). In other words, the net changes in biomass and harvest index are reflected in grain yield (Gholipoor, 2009). The high plant biomass could lead to the production of more grains per plant and consequently grain yield per unit area (Table 1). This is in agreement with the results of another research about rice (Soni et al., 2013), cowpea (Hosseinian \& Majnoun-Hoseini, 2015) and soybean (Ball et al., 2000). Decreasing grain yield per unit area under drought stress can be largely attributed to considerable reduction in number of grains per plant rather than grain mass (Table 1). This is also supported by the other researchers (Gonzalez et al., 2003; Borra's et al., 2004; Dalil \& Ghassemi-Golezani, 2012).

Production of comparatively more grains per plant, heavier grains and higher plant biomass in late maturing cultivar ('SC704') (Table 1) could be attributed to longer period of radiation use and energy store of this cultivar, compared with other cultivars (Sangoi, 2000). These differences resulted in higher grain yield of this cultivar, compared with 'NS640' (mid maturing cultivar) and 'DC303' (early maturing cultivar). Banzinger et al. (2000) reported that number of grains per plant and grain mass could help to determine the grain yield of maize. Variation of these yield components among maize cultivars directly influences grain yield per unit area. The greatest harvest index of 'SC704' under different irrigation intervals (Table 1) suggests a high ratio of grain yield to plant biomass in this cultivar, compared with 'NS640' and 'DC303'. So, harvest index positively related with grain yield and negatively related with plant biomass.

\section{CONCLUSION}

Drought stress enhances leaf temperature, but reduces chlorophyll content, maximum efficiency of photosystem II, number of grains per plant, grain mass, plant biomass and consequently grain yield and harvest index in maize cultivars, depending on duration of stress. These reductions increase with increasing water limitation. The late maturing maize cultivar ('SC704') showed a superior performance under different irrigation intervals, compared with early and midmaturing cultivars. Therefore, delayed maturation of maize may be an advantage in areas with sufficient or slightly limited water availability during crop growth and development.

\section{REFERENCES}

Anjum, S.A., Xie, X., Wang, L., Saleem, M., Man, C., Lei, W. (2011). Morphological, physiological and biochemical responses of plants to drought stress. African Journal of Agricultural Research, 6, 20262032.

Aslam, M., Zamir, M.S.I., Afzal, I., Yassen, M., Mubeen, M., Shoaib, A. (2013). Drought stress, its effect on maize production and development of drought tolerance through potassium application. Cercetari Agronomice in Moldova, 2, 99-114.

Badoni, A., Nautiyal, M., Gusain, K., Kaur, M., Dhiman, R., Bisht, C., Chauhan, J.S. (2009). Effect of water uptake on germinability in seeds of some medicinal plants. Journal of American Science, 5, 123-28.

Ball, R.A., Purcell, L.C., Vories, E.D. (2000). Shortseason soybean yield compensation in response to population and water regime. Crop Science, 40, 1071-1078. doi:10.2135/cropsci2000.4041070x

Banzinger, M., Edmeades, G.O., Beck, D., Bellon, M. (2000). Breeding for drought and nitrogen stress tolerance in maize: From theory to practice. Mexico, D.F.: CIMMYT.

Borra's, L., Slafer, G.A., Otegui, M.E. (2004). Seed dry weight response to source-sink manipulations in wheat, maize and soybean: a quantitative 
reappraisal. Field Crops Research, 86, 131-46. doi:10.1016/j.fcr.2003.08.002

Brestic, M., Zivcak, M. (2013). PSII fluorescence techniques for measurement of drought and high temperature stress signal in crop plants: protocols and applications. In G.R. Rout \& A.B. Das (Eds), Molecular stress physiology of plants (pp. 427). India, Springer. doi:10.1007/978-81-322-0807-5_4

Campos, H., Cooper, M., Habben, J.E., Edmeades, G.O., Schussle, J.R. (2004). Improving drought tolerance in maize view from industry. Field Crop Research, 90, 19-34. doi:10.1016/j.fcr.2004.07.003

Dalil, B., Ghassemi-Golezani, K. (2012). Changes in leaf temperature and grain yield of maize under different levels of irrigation. Research on Crops, 13, 481- 485 .

Ghassemi-Golezani, K., Dalil, B., DabbaghMohammadi Nasab, A., Zehtab-Salmasi, S. (2008a). The Response of chickpea cultivars to field water deficit. Notulae Botanicae Horti Agrobotanici Cluj-Napoca, 36, 25-28.

Ghassemi-Golezani, K., Dalil, B., Moghaddam, M., Raey, Y. (2011). Field performance of differentially deteriorated seed lots of maize (Zea mays) under different irrigation treatments. Notulae Botanicae Horti Agrobotanici Cluj-Napoca, 39, 160-163.

Ghassemi-Golezani, K., Khomari, S., Valizadeh, M., Alyari, H. (2008b). Changes in chlorophyll content and fluorescence of leaves of winter rapeseed affected by seedling vigor and cold acclimation duration. Journal of Food, Agriculture \& Environment, 6, 196-199.

Ghassemi-Golezani, K., Lotfi, R. (2015). The impact of salicylic acid and silicon on chlorophyll a fluorescence in mung bean under salt stress. Russian Journal of Plant Physiology, 62, 611-616. doi:10.1134/S1021443715040081

Gholipoor, M. (2009). Evaluating the response of rainfed-chickpea population density in Iran, using simulation. World Academy of Sciences, Engineering \& Technology, 49, 97-104.

Gonzalez, F.G., Slafer, G.A., Miralles, D.J. (2003). Grain and floret number in response to photoperiod during stem elongation in fully and slightly vernalized wheat. Field Crops Research, 81, 17-27. doi:10.1016/S0378-4290(02)00195-8

Gregoriou, K., Pontikis, K., Vemmos S. (2007). Effects of reduced irradiance on leaf morphology, photosynthetic capacity, and fruit yield in olive (Olea europaeaL.). Photosynthetica, 45, 172-181. doi:10.1007/s11099-007-0029-x
Hermans, C., Smeyers, M., Rodriguez, R.M., Eyletters, M., Strasser, R.J., Delhaye, J.P. (2003). Quality assessment of urban trees: A comparative study of physiological characterization, airborne imaging and on site fluorescence monitoring by the O-J-I-Ptest. Journal of Plant Physiology, 160, 81-90. doi:10.1078/0176-1617-00917

Hosseinian, H., Majnoun-Hoseini, N. (2015). Analysis of correlation coefficients between grain yield and yield components in cowpea genotypes under normal and drought conditions stress. Iranian Journal of Field Crop Science, 45, 575-583.

Huang, R., Birch, C.J., George, D.L. (2006). Water use efficiency in maize production. The challenge and improvement strategies. 6th Triennial Conference, Australia.

Krause, G.H., Weis, E. (1991). Chlorophyll fluorescence and photosynthesis: The basics. Annual Review of Plant Physiology and Plant Molecular Biology, 42, 313-349. doi:10.1146/annurev.pp.42.060191.001525

Ladjal, M., Epron, D., Ducrey, M. (2000). Effects of drought preconditioning on thermo tolerance of photosystem II and susceptibility of photosynthesis to heat stress in cedar seedlings. Tree Physiology, 20, 1235-1241. doi:10.1093/treephys/20.18.1235

Larcher, W. (2000). Temperature stress and survival ability of Mediterranean sclerophyllous plants. Plant Biosystems, 134, 279-95. doi:10.1080/11263500012331350455

Lotfi, R., Pessarakli, M., Gharavi-Kouchebagh, P., Khoshvaghti, H. (2015). Physiological responses of Brassica napus to fulvic acid under water stress: Chlorophyll a fluorescence and antioxidant enzyme activity. The Crop Journal, 3, 434-439. doi:10.1016/j.cj.2015.05.006

Lu, Z., Chen, J., Percy, R.G., Zeiger, E. (1997). Photosynthetic rate, stomatal conductance and leaf area in two cotton species (Gossypium barbadense and Gossypium hirsutum) and their relation with heat resistant and yield. Austuralian Journal of Plant Physiology, 24, 693-700. doi:10.1071/PP97056

Mohammadian, R., Moghaddam, M., Rahimian, H., Sadeghian, S.Y. (2005). Effect of early season drought stress on growth characteristics of sugar beet genotypes. Turkish Journal of Agriculture and Forestry, 29, 357-68.

Monneveux, P., Sanchez, C., Beck, D., Edmeds, G.E. (2006). Drought tolerance improvement in topical maize source populations: evidence of progress. Journal of Crop Science, 46, 180-191. doi:10.2135/cropsci2005.04-0034

Acta agriculturae Slovenica, 111 - 1, marec 2018 
Paul Parkhill, J., Maillet, G., Gullen, J.J. (2001). Fluorescence-based maximal quantum yield for PS II as a diagnostic of nutrient stress. The Journal of Physiology, 37, 517-529.

Rizza, F., Pagani, D., Stanca, A.M., Cattivelli, L. (2001). Use of chlorophyll florescence to evaluate the cold acclimation and freezing tolerance of winter and spring oats. Plant Breeding, 120, 389396. doi:10.1046/j.1439-0523.2001.00635.x

Rong-Hua, L., Pei-Guo, G., Baum, M., Grando, S., Ceccarelli, S. (2006). Evaluation of chlorophyll content and fluorescence parameters as indicators of drought tolerance in barley. Agricultural Science in China, 5, 751-757. doi:10.1016/S16712927(06)60120-X

Roohi, E., Tahmasebi-Sarvestani, Z., Modarres-Sanavy, S.A.M. Siosemardeh, A. (2013). Comparative study on the effect of soil water stress on photosynthetic function of triticale, bread wheat, and barley. Journal of Agricultural Science \& Technology, 15, 215-228.

Rimski-Korsakov, H., Rubio, G., Lavado, R.S. (2009). Effect of water stress in maize crop production and nitrogen fertilizer fate. Journal of Plant Nutrition, 32, 565-578. doi:10.1080/01904160802714961

Rohacek, K. (2002). Chlorophyll fluorescence parameters: the definitions, photosynthetic meaning, and mutual relationship. Photosynthetica, 40, 13-29. doi:10.1023/A:1020125719386

Sabir, P., Ashraf, M., Hussain, M., Jamil, A. (2009). Relationship of photosynthetic pigments and water relations with salt tolerance of roso millet (Panicum miliaceum L.) accessions. Pakistan Journal of Botany, 41, 2957-2964.

Salvucci, M.E., Crafts-Brandner, J.S. (2004). Inhibition of photosynthesis by heat stress: the activation state of rubisco as a limiting factor in photosynthesis. Physiologia Plantarum, 120, 179-86. doi:10.1111/j.0031-9317.2004.0173.x

Sangoi, L. (2000). Understanding plant density effects on maize growth and development: an important issue to maximize grain yield. Ciencia Rural, 31, 159-168. doi:10.1590/S0103-84782001000100027

Shahenshah, Isoda, A. (2016). Effects of water stress on leaf temperature and chlorophyll fluorescence parameters in cotton and peanut. Plant Production Science, 13, 269-278. doi:10.1626/pps.13.269

Soltani, A., Khooie, F.R., Ghassemi-Golezani, K., Moghaddam, M. (2001). A simulation study of chickpea crop response to limited irrigation in a semi-arid environment. Agricultural Water Management, 49, 225-37. doi:10.1016/S03783774(00)00143-8

Soni, S., Yadav, V.K., Pratap, N., Bhadana, V.P., Ram, T. (2013). Selection criteria, yield relationship with component traits and grouping of tropical japonica, indica lines and derived hybrids of rice (Oryza sativa L.). SAARC Journal of Agriculture, 11, 1732.

Valifard, M., Moradshahi, A., Kholdebarin, B. (2012). Biochemical and physiological responses of two wheat (Triticum aestivum L.) cultivars to drought stress applied at seedling stage. Journal of Agricultural Science \& Technology, 14, 1567-1578.

Zarco-Tejada, P.J., Berni, J.A.J., Suarez, L., SepulcreCanto, G., Morales, F., Miller, J.R. (2009). Imaging chlorophyll fluorescence with an airborne narrowband multispectral camera for vegetation stress detection. Remote Sensing \& Environment, 113, 1262-1275. doi:10.1016/j.rse.2009.02.016 